\title{
Employment of advanced oxidation processes in the degradation of a textile dye mixture: evaluation of reaction parameters, kinetic study, toxicity and modeling by artificial neural networks
}

Emprego de processos oxidativos avançados na degradação de uma mistura de corantes têxteis: avaliação de parâmetros de reação, estudo cinético, toxicidade e modelagem por redes neurais artificiais

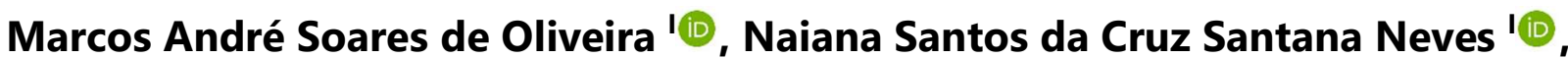 Rayany Magali da Rocha Santana ' ${ }^{(\mathbb{O})}$, Alex Leandro Andrade de Lucena '(1), Léa Elias Mendes Carneiro Zaidan 'ㅁ, Vanessa de Oliveira Marques Cavalcanti '10, Gilson Lima da Silva '10, Daniella Carla Napoleão '(i)}

\footnotetext{
' Federal University Of Pernambuco, Recife, PE, Brazil
}

\section{ABSTRACT}

Organic contaminants in industrial effluents threaten the quality of water resources, especially due to their resistance to natural degradation. The textile industry gain relevance, considering that it generates large volumes. This work aimed to evaluate the efficiency of different advanced oxidation processes (AOP) for the degradation of the mixture textile dyes in solution. After optimization of the main parameters involved in the applied processes and systems, the AOP with greater efficiency in the degradation of the compounds was the photo-Fenton/UV-C (92\%) after 360 min of treatment. The experimental data showed a better fit to the Chan and Chu kinetic model and trough an evaluation using artificial neural networks it was possible to predict the maximum degradation achievable by the dye mixture. The toxicity assays, using multiple species of seeds indicated a treated solution with no toxic effects and that the applied methodology can be used without affecting the water resources.

Keywords: Photoperoxidation; Fenton process; UV-C radiation; Treatment 


\section{RESUMO}

Contaminantes orgânicos em efluentes industriais ameaçam a qualidade dos recursos hídricos por apresentarem resistência à degradação natural. Neste sentido, a indústria têxtil ganha relevância, pois é responsável pela geração de grandes volumes de efluentes líquidos. O presente trabalho avaliou a eficiência de diferentes processos oxidativos avançados (POA) para degradação de uma mistura de corantes têxteis em solução. Após testes de eficiência e otimização dos principais parâmetros envolvidos nos processos e sistemas aplicados, o POA que apresentou maior eficiência na degradação dos compostos foi o foto-Fenton/UV-C (92\%) de degradação após $360 \mathrm{~min}$. Os dados experimentais do POA foto-Fenton/UV-C apresentaram melhor ajuste ao modelo de Chan e Chu e através da avaliação matemática usando rede neural artificial foi possível prever a degradação máxima da mistura de corantes. O estudo de toxicidade com sementes indicou que a solução tratada não possui efeitos tóxicos, podendo o tratamento proposto ser utilizado sem afetar recursos hídricos.

Palavras-chave: Fotoperoxidação; Processos Fenton; Radiação UV-C; Tratamento

\section{INTRODUCTION}

The textile industrial sector plays an important economic role in the development of many countries, especially the emerging ones, however, it is also known as one of the five largest consumers of water (Holkar et al., 2016). Given this, Brazil stands out for being the world second largest manufacturer of jeans and the fifth largest producer of textile products (ABIT, 2019). Allied with this high production, several points of textile industrial pollution are present, through the discharge of its effluents and residues directly in the water bodies (Dias et al., 2018).

It is estimated that one-fifth of all water pollution caused by the textile sector comes from the dyeing and treatment stages adopted in the production process (Pazdzior; Bilińska; Ledakowicza, 2019). Several synthetic chemical substances are used for the transformation of raw materials into textile products (Ferreira et al., 2019). Among them, there are the textile dyes, which are responsible for giving color to the materials (Zhou et al., 2019).

About $15 \%$ of these compounds are lost along with the production, due to their low fixation on the products, this fact increases the concern related to the presence of these 
contaminants on the aquatic matrices. The presence of dyes in effluents increases their complexity, increasing the color of the water bodies, interfering in the photosynthesis process, generating higher values of chemical oxygen demand (COD) and biochemical oxygen demand (BOD) (al-Mamun et al., 2019; Aquino et al., 2019; Liang et al., 2018). Thus, treating these effluents and evaluating the efficiency of the wastewater treatment plants (WWTP) to do so, are essential (Napoleão et al., 2013). Studies show that conventional treatment processes (physical, chemical, and biological), generally applied in the WWTP, do not promote the complete degradation of persistent organic pollutants, such as dyes, presenting possible formation of aromatic amines, compounds with a carcinogenic and mutagenic character. This implies the need for alternative methodologies for more incisive treatments of these recalcitrant contaminants (Hitam; Jalil, 2020; Oliveira et al., 2014; Rawat et al., 2018).

Given this, the use of advanced oxidation processes (AOP) appears as an alternative, since its applicability on the degradation and mineralization of different organic contaminants, converting them into carbon dioxide $\left(\mathrm{CO}_{2}\right)$, water, and inorganic salts (Syam Babu et al., 2019). Among the most used AOP are the Fenton and photo-Fenton processes, the photoperoxidation, and the heterogeneous photocatalysis. These processes have been used as an efficient alternative in the treatment of pharmaceutical products (Monteiro et al., 2018), dyes (Kumar et al., 2020), phenolic compounds (Zaidan et al., 2017), among other organic compounds.

The AOPs work through the use of a strong oxidizing agent, usually oxygen peroxide $\left(\mathrm{H}_{2} \mathrm{O}_{2}\right)$ and/or Ozone $\left(\mathrm{O}_{3}\right)$, aiming at the generation of highly oxidative hydroxyl radicals $(\cdot \mathrm{OH})$, which act non-selectively to promote the degradation of pollutants (Changotra et al., 2019). In the case of the Fenton process, the production of $\cdot \mathrm{OH}$ takes place in an acid medium in the presence of ferrous ions $\left(\mathrm{Fe}^{2+}\right)$. These ions act as electron donors and oxidize to $\mathrm{Fe}^{3+}$ due to the decomposition of hydrogen peroxide. In Equations 1 and 2 the mechanism of the oxidation reaction through the Fenton process is demonstrated (Giannakis, 2019; Zhu et al., 2019). 


$$
\begin{aligned}
& \mathrm{Fe}^{2+}+\mathrm{H}_{2} \mathrm{O}_{2} \rightarrow \mathrm{Fe}^{3+}+\mathrm{OH}^{-}+\mathrm{HO} \cdot \\
& \mathrm{HO} \cdot+\mathrm{Fe}^{2+} \rightarrow \mathrm{Fe}^{3+}+\mathrm{OH}^{-}
\end{aligned}
$$

From the production of hydroxyl radicals, then the degradation propagates through the oxidation of organic substances contained in the pollutant load, shown by Equation 3.

$$
\mathrm{HO} \cdot+\mathrm{RH} \rightarrow \mathrm{H}_{2} \mathrm{O}+\mathrm{R}
$$

The formation of this organic radical occurs due to the abstraction of the hydrogen atom, caused by hydroxyl radicals, which when bound to molecular oxygen $\left(\mathrm{O}_{2}\right)$ forms the peroxide radical $\left(\mathrm{RO}_{2} \bullet\right)$. Thus, there is the promotion of chain reactions leading to the degradation of organic compounds, and the consequent formation of AOP products (Fioreze; Santos; Schmachtenberg, 2014; Sahoo; Marbaniang; Sharan, 2016). This type of reaction generally occurs with aliphatic hydrocarbons, however, Gautam, Kumar, and Lokhandwala (2019) explain that the $\cdot \mathrm{OH}$ radicals attack hydrocarbons, such as aromatics (through electrophilic addition) and chlorines (by electron transfer). These authors also claim that the $\cdot \mathrm{OH}$ has a short lifespan, therefore, requires generation in situ, which can be accomplished by combining oxidizing agents, irradiation, and catalysts.

Miklos et al. (2018) state that the application of a radiation source, visible (Vis) or ultraviolet (UV) helps in breaking down the $\mathrm{H}_{2} \mathrm{O}_{2}$ molecule, increasing the generation of free hydroxyl radicals and, consequently, the mineralization of organic compounds. This process is known as photo-Fenton, in which $\mathrm{Fe}^{2+}$ ions regenerate from the reaction between $\mathrm{Fe}^{3+}$ ions and hydrogen peroxide, in solution as shown in Equation 4 (Giannakis, 2019; Slamani et al., 2018).

$$
\mathrm{Fe}^{3+}+\mathrm{H}_{2} \mathrm{O}_{2}+h v \rightarrow \mathrm{Fe}^{2+}+\mathrm{H}^{+}+\mathrm{OH}^{-}
$$


Martins et al. (2011) compared the Fenton process with other AOP (photo-Fenton and peroxidation) for the treatment of synthetic textile effluent. The authors found a discoloration efficiency for the black biozol UC dye (100 mg. $\left.\mathrm{L}^{-1}\right)$ in $120 \mathrm{~min}$, reaching $86.2 \%$ of chromophore degradation. It was also verified, by monitoring the chemical oxygen demand (COD), a 65\% carbonaceous matter conversion.

However, in different situations, the Fenton process alone is not efficient to fully degrade some contaminants, requiring the use of a light source. Dias et al. (2013) used the photo-Fenton process with UV-A radiation to treat aqueous solutions of the Remazol black$B$ dye, in concentrations ranging from 15 to $99 \mathrm{mg} \cdot \mathrm{L}^{-1}$. After $120 \mathrm{~min}$, the authors were able to mineralize $90 \%$ of the total organic carbon as well as degrade $90 \%$ of the solution color.

The AOP as other types of processes that involves chemical oxidation reactions has kinetics that controls the process and can be modeled. This type of process, in general, follows kinetic models of pseudo-first order ( $\mathrm{C} / \mathrm{CO}$ versus time), which have been applied to describe the treatment of different organic substances (Sarkar; Bhattacharjee; Curcio, 2015; Khuzwayo; Chirwa, 2017).

Due to their molecular constitution, azoic dyes have certain toxicity (Zanoni; Yamanaka, 2016). Although the application of AOP degrades these organic molecules, these processes can originate intermediate chemical species harmful to the environment, and therefore, the evaluation of the toxic effects caused by solutions of dyes and textile effluents before and after the application of AOP is of fundamental importance (Bour et al., 2015; Oancea; Meltzer, 2014).

According to Sparling (2016), toxicity tests should observe death, reproduction, germination, or change in the growth of indicator individuals. Among the organisms most used for these tests are seeds (Rawat et al., 2018; Moraes et al., 2020), microcrustaceans (Garcia; Rosa; Borrely, 2020; Punzi et al., 2015), and bacteria (Huang et al., 2017; Nascimento et al., 2018).

In an interview scheduled with employees of a textile dye production plant in the state of Pernambuco/Brazil, it was found that among the dyes most manufactured by the industry are the direct 22 (DB22), acid black 172 (AB172), and reactive black 5 (RB5). In the literature, 
studies on the interaction and influence on the degradation efficiency of an aqueous solution containing these three dyes in a mixture have not been found. Thus, the present work aims to analyze the degradation of aqueous solutions containing the textile dyes DB22, AB172, and RB5 through different types of advanced oxidation processes. With the efficiency of the photoperoxidation, Fenton and photo-Fenton processes under UV-A, UV-A, and artificial and natural solar irradiations being evaluated. Besides, the reaction kinetics and the toxicity of the solution were monitored before and after treatment with the most efficient $A O P$, as well as mathematical modeling of an artificial neural network for the studied system.

\section{MATERIALS AND METHODS}

\subsection{Identification and quantification of the dyes}

The identification of the characteristic wavelengths $(\lambda)$ of the matrix containing the mixture of textile dyes direct black 22 (DB22) (CAS 6473-13-8), acid black 172 (AB172) (CAS 61847-77-6/57696-14-8), and reactive black 5 (RB5) (CAS 17095-24-8), provided by Exatacor, occurred from spectral scans. These were performed on an ultraviolet/visible spectrophotometer (UV/Vis) (Thermoscientific), with an operating range between 200 and $900 \mathrm{~nm}$. It is noteworthy that the $\mathrm{pH}$ of the solution was varied from 2 to 6 to find out if this parameter influences the absorption spectrum. The quantification of the analytes before and after the degradation processes was performed using analytical curves (from 1 to $30 \mathrm{mg} \cdot \mathrm{L}^{-1}$ ) constructed for the $\lambda$ previously identified. 
Figure 1 - Molecule structure of azo dyes: a) direct black 22 b) acid black 172, (C) reactive black 5

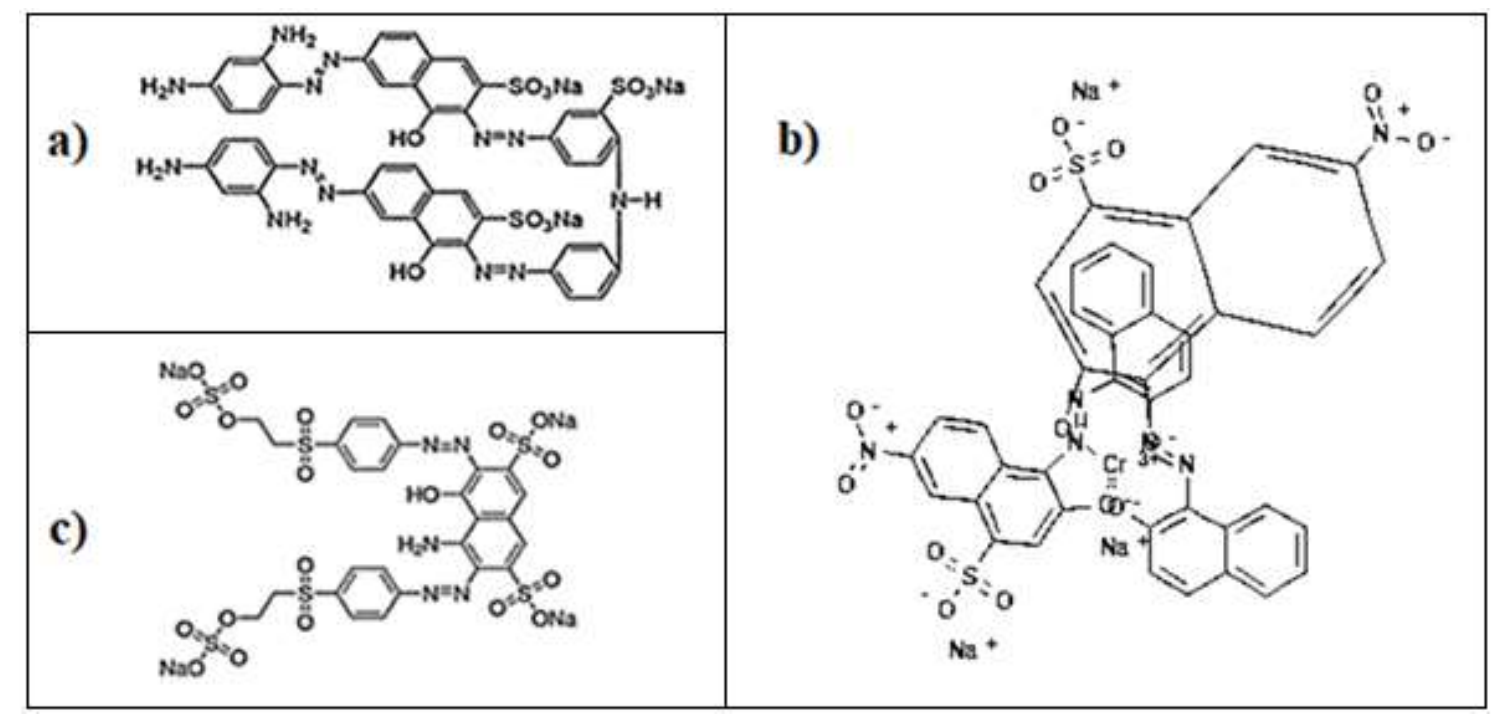

Fonte: Colour Index, Pubchem (2021)

\subsection{Preliminary and univariate study}

The degradation tests via photo-Fenton (PF) and photoperoxidation (PP) were performed for the UV-C (Charamba et al., 2017) radiation and artificial (Santana et al., 2017) and natural solar radiations.

In addition, the efficiency of the Fenton process was also evaluated. For this purpose, $50 \mathrm{~mL}$ of the aqueous solution with an initial concentration of $20 \mathrm{mg} \cdot \mathrm{L}-1$ of each dye were subjected to treatments for $60 \mathrm{~min}$. In the preliminary tests, $100 \mathrm{mg} \cdot \mathrm{L}-1$ of hydrogen peroxide (H2O2) (Scientific Exodus, 35\%) were used, also $5 \mathrm{mg} \cdot \mathrm{L}-1$ of iron in the form of ferrous sulfate heptahydrate (FeSO4.7H2O) (F. Maia) was applied for the Fenton and photoFenton processes, with the solution $\mathrm{pH}$ adjusted to 3.

Additional photolysis tests were performed to assess the radiation contribution to the PF and PP processes. Photon emissions were quantified with a radiometer (Emporionet) and the efficiency of the process was assessed by obtaining the degradation percentage (\%) from the samples after submission to the AOP. Based on the results of this initial study and 
knowing the most efficient $A O P$, the operational conditions were optimized through univariate studies of the process variables.

Thus, the following variables were varied, the [H2O2] from 40 to $140 \mathrm{mg} \cdot \mathrm{L}-1$, the [Fe] from 1 to $5 \mathrm{mg} \cdot \mathrm{L}-1$, the $\mathrm{pH}$ from 2 to 4 and the volume of the solution to be treated (200, $500,1000 \mathrm{~mL}$ ). With each of these parameters being evaluated at a time, starting with the [H2O2] and keeping [Fe] fixed at $1 \mathrm{mg} \cdot \mathrm{L}-1, \mathrm{pH}=3$ and $\mathrm{V}=50 \mathrm{~mL}$. Then, after identifying the most efficient [H2O2], the [Fe] was evaluated, and so on.

\subsection{Kinetics and toxicity evaluation}

Based on the best experimental conditions defined previously, tests were performed to monitor the degradation kinetics of the mixture of dyes under study. Thus, a $1000 \mathrm{~mL}$ solution with $20 \mathrm{mg} \cdot \mathrm{L}^{-1}$ of each dye was submitted to the $\mathrm{AOP}$, with aliquots being removed at regular intervals for a period of $360 \mathrm{~min}$, having previously analyzed the influence of lower $\left(5,10,15 \mathrm{mg} \cdot \mathrm{L}^{-1}\right)$ and higher $\left(30 \mathrm{mg} \cdot \mathrm{L}^{-1}\right)$ concentration than the adopted one. Then, the fit of the kinetic data to the first-order (Equation 5), second-order (Equation 6), and the Chan and Chu (2003) (Equation 7) models were evaluated.

$$
\begin{aligned}
& \mathrm{C}=\mathrm{C}_{0} \cdot \mathrm{e}^{-\mathrm{k}_{1} \cdot \mathrm{t}} \\
& \frac{1}{\mathrm{C}}=\frac{1}{\mathrm{C}_{0}}+\mathrm{k}_{2} \cdot \mathrm{t} \\
& \mathrm{C}=\mathrm{C}_{0} \cdot\left(1-\frac{\mathrm{t}}{\rho+\sigma \mathrm{t}}\right)
\end{aligned}
$$

In which, $C$ is the concentration of the analyte $\left(\mathrm{mg}^{-1} \mathrm{~L}^{-1}\right)$ at a given time; $\mathrm{C}_{0}$ the initial concentration ( $\left.\mathrm{mg}^{-\mathrm{L}^{-1}}\right), \mathrm{k}_{1}$, and $\mathrm{k}_{2}$ are the first and second-order velocity constants, given in $\mathrm{min}^{-1}$ and $\mathrm{mg}^{-1} \cdot \mathrm{min}^{-1}$, respectively; and $\mathrm{t}$ is reaction time $(\mathrm{min})$. The values of the linear regression coefficient $\left(R^{2}\right)$ and the parameters of the Chan and Chu model were evaluated 
as indicators of the better fit and efficiency of the applied process. With $\rho$ being the rate of the reaction and $\mathrm{e} \sigma$ the maximum oxidative capacity of the process for this model.

The toxicity tests were performed with lettuce (Lactuca sativa), carrot (Daucus carota subsp. Sativus), arugula (Eruca vesicaria ssp. Sativa), and watercress seeds (Nasturtium officinale). These were exposed to solutions containing the contaminants before and after the treatment with the AOP for a period of $120 \mathrm{~h}$, at a temperature of $25 \pm 1{ }^{\circ} \mathrm{C}$ and in the absence of light.

In these tests, which were performed in triplicate, 20 seeds were placed on filter paper in Petri dishes and moistened with $4 \mathrm{~mL}$ of the solution to be analyzed. Also, control tests were performed: negative (distilled water) and positive (3\% boric acid solution). At the end of the incubation, the seeds that showed germination were counted, with subsequent evaluation of root growth. Then, as described by Young et al. (2012), the relative growth index (RGI) (Equation 8) and the germination index (GI) (Equation 9) were calculated.

$$
\begin{aligned}
& R G I=R L S / R L C \\
& G I(\%)=R G I .(G S S / G S C) .100
\end{aligned}
$$

Being, RLS the root length of the sample, and RLC the root length in the negative control. While GSS is the number of seeds germinated in the sample and GSC the number of seeds germinated in the negative control.

\subsection{Artificial neural networks modeling}

The Statistica 6.0 software was used to generate artificial neural networks (ANN), to discover patterns and correlations in the experimental data obtained through the study. Therefore, the following variables were selected as the input: [Fe], $\left[\mathrm{H}_{2} \mathrm{O}_{2}\right], \mathrm{pH}$, dye initial concentration, and time.

For the construction of the ANN, training was carried out with 2000 iterations. A Multi Layer Percepton (MLP) configuration was used, applied with a propagation signal made by 
neurons distributed in it, both in the hidden and in the output layers. It is worth mentioning that the data for feeding the network were distributed as follows: training (70\%), testing (15\%), and validation (15\%). With the following functions testes, sinusoidal transfer, logistics, identity, hyperbolic, and exponential tangential.

\section{RESULTS AND DISCUSSION}

\subsection{Dyes identification and quantification}

As mentioned in item 2.1, the dye mixture aqueous solution was subjected to spectral scanning, with the influence of the $\mathrm{pH}$ on the absorbance spectrum being also evaluated. The obtained spectra are shown in Figure 2.

Figure 2 - UV/Vis spectrum: a) three dye mixture aqueous solution and b) Influence of the $\mathrm{pH}$ variation in the solution, c) spectrum of individual and mixed dyes
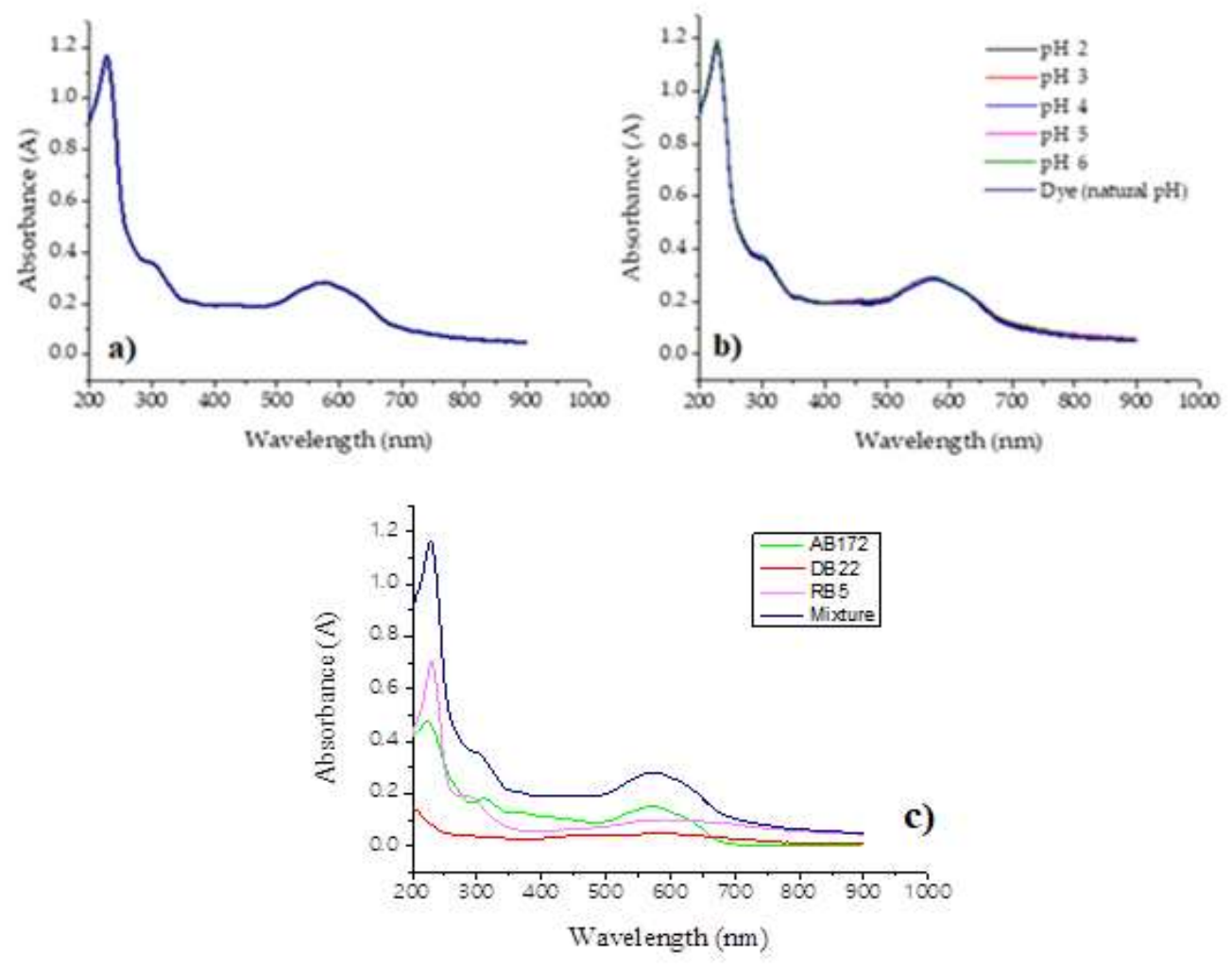

Source: Authors (2021) 
The analysis of Figure 2 allows verifying the presence of two characteristic wavelengths $(\lambda)$ for the textile dye mixture under study. The first one was observed at 228 $\mathrm{nm}$ and the second at $576 \mathrm{~nm}$. The first peak refers to the presence of aromatic groups, while the second represented the chromophoric groups, responsible for coloring. It is also observed that the three dyes have the same characteristic wavelengths, which reinforces their choice. It was found that the $\mathrm{pH}$ variation did not cause a displacement of these peaks, indicating that the analytical curves could be constructed at the natural $\mathrm{pH}(5-6)$ of the dye mixture aqueous solution. Such curves presented the following equations: $y=0.0235243 x$ for $576 \mathrm{~nm}$ and $\mathrm{y}=0.1126956 \mathrm{x}$ for $228 \mathrm{~nm}$, with linear regression coefficient (R2) equal to 0.99 for both. Once identified the $\lambda$ and built the analytical curves, then followed the treatment step for the textile dye mixture solution.

\subsubsection{Preliminary study}

For the experiments to be carried out, natural solar radiation and the two bench reactors described in item 2.2 were used. The sunlight reactor had a photon emission of 13.80 W. $\mathrm{cm}^{-2}$ in the visible range, $5.90 \times 10^{-3}$ W. $\mathrm{cm}^{-2}$ in the UV-A/UV-B range, and $8.96 \times 10^{-}$ ${ }^{4} \mathrm{~W} . \mathrm{cm}^{-2}$ in the UV-C range, while the UV-C reactor had photoemission of $1.85 \times 10^{-3} \mathrm{~W} . \mathrm{cm}^{-2}$. For the natural solar radiation, the emission was $1.57 \times 10^{4} \mathrm{~W} \cdot \mathrm{cm}^{-2}$ photons in the visible range, $3.47 \times 10^{-4} \mathrm{~W} . \mathrm{cm}^{-2}$ in the UV-A/UV-B range, and of $10^{-4} \mathrm{~W} . \mathrm{cm}^{-2}$ in the UV-C range.

Initially, the contribution of the photolysis process for each of the radiation (UV-C; artificial solar and natural solar) was evaluated. This treatment showed maximum degradation values of $41 \%$ and $45.2 \%$, respectively for the chromophores and aromatics $\lambda$, in the UV-C reactor. When using the two solar radiations, degradations of less than $25 \%$ were obtained for both $\lambda$. Knowing that commercial organic dyes are designed to be resistant to light, even for different radiations, direct photolysis did not show significant degradation for the dyes under study, showing that the decay rated strongly depend on the photosensitivity, chemical structures, solvent conditions, and its reactivity with the photon emission source used. In this sense, for some azo dyes, the closer the solution is to neutrality, the effective the photolysis process will be (Almomani et al., 2002; Chu; Tsui, 2002; Zhang; 
Zhang, 2020). In this sense, there is a need for the use of reagents that generate hydroxyl radicals and increase the effectiveness of the degradation of the contaminants.

In this way, the photoperoxidation process reached $66.6 \%$ degradation for both $\lambda$ when artificial solar radiation was applied. This was the radiation that demonstrated the greatest efficiency since the use of natural solar and UV-C radiations led to degradations up to $55 \%$ at $576 \mathrm{~nm}$ and $51.2 \%$ at $228 \mathrm{~nm}$. It can be seen, therefore, that the combined use of radiation and the oxidizing agent favored the degradation of textile dyes. Rosa et al. (2020) state that in this type of AOP there is an intensification of the $\cdot \mathrm{OH}$ production, due to the homolytic fission suffered by the $\mathrm{H}_{2} \mathrm{O}_{2}$ when in the presence of radiation. Thus, the authors state that the oxidation process leads to greater mineralization of organic substances that contain reactive aromatic and unsaturated bonds.

By using the Fenton process a color degradation of $60.9 \%$ was obtained, which was also higher than that observed for the photolysis process. However, the degradation reactions led to a growth of aromatic compounds in the solutions ( $\geq 21.6 \%$ ), thus indicating the formation of intermediates at the $228 \mathrm{~nm}$ wavelength. Therefore, it can be said that using this process alone does not add sufficient effectiveness to treat the aromatic groups present in the dye solution. This is due, according to Nidheesh et al. (2013), to the drop in reaction yield after $30 \mathrm{~min}$ in this process, a period in which hydrogen peroxide is slowly consumed, thus decreasing the concentration of ferrous ions and available hydroxyl radicals.

Then, it was studied whether it is advantageous to apply the radiation in conjunction with the Fenton reagent (photo-Fenton process). The efficiency of the photo-Fenton AOP to degrade the aqueous solution was evaluated in different types of radiation after $60 \mathrm{~min}$.

Amongst the two solar radiations, the artificial one presented better efficiency results, with the degradation of around $70 \%$ for both $\lambda$. While the dye degradation by applying natural solar radiation showed a $6 \%$ difference degradation efficiency, being $>63 \%$ for both $\lambda$. This is related to the constancy of photons emitted by the artificial lamp, a fact that does not happen when using natural solar radiation, where there may be moments of cloudiness that corroborate thus with a lower efficiency of the solar photo-Fenton process under natural irradiation. 
When applying the UV-C radiation, degradations greater than $74.5 \%$ were obtained for both $\lambda$, which can be associated with the emission range of this type of radiation (between 100 and $280 \mathrm{~nm}$ ). This type of radiation has a higher energy capacity and acts more effectively in the $\cdot \mathrm{OH}$ formation process when compared to artificial and natural solar radiation (Adak et al., 2015). It is noticed that the photo-Fenton process shows a greater efficiency in degrading the dye solution, especially with the use of artificial lamps.

In view of the difference between the UV-C and artificial solar radiation being of only $5 \%$, it was decided to continue the univariate study of the photo-Fenton process by applying both radiations.

\subsubsection{Univariate study}

To improve the efficiency of the process, the influence of the operational parameters for the two selected radiations (artificial solar and UV-C) was evaluated. At first, the effect of the concentration of $\mathrm{H}_{2} \mathrm{O}_{2}\left(\left[\mathrm{H}_{2} \mathrm{O}_{2}\right]\right)$ on the degradation of the dyes by the photo-Fenton process was evaluated (Figure 3).

Figure 3 - Influence of the $\left[\mathrm{H}_{2} \mathrm{O}_{2}\right]$ variation on the efficiency of the photo-Fenton process under UV-C and sunlight radiation for the $\lambda$ of $576 \mathrm{~nm}$ (a) and $228 \mathrm{~nm}$ (b)
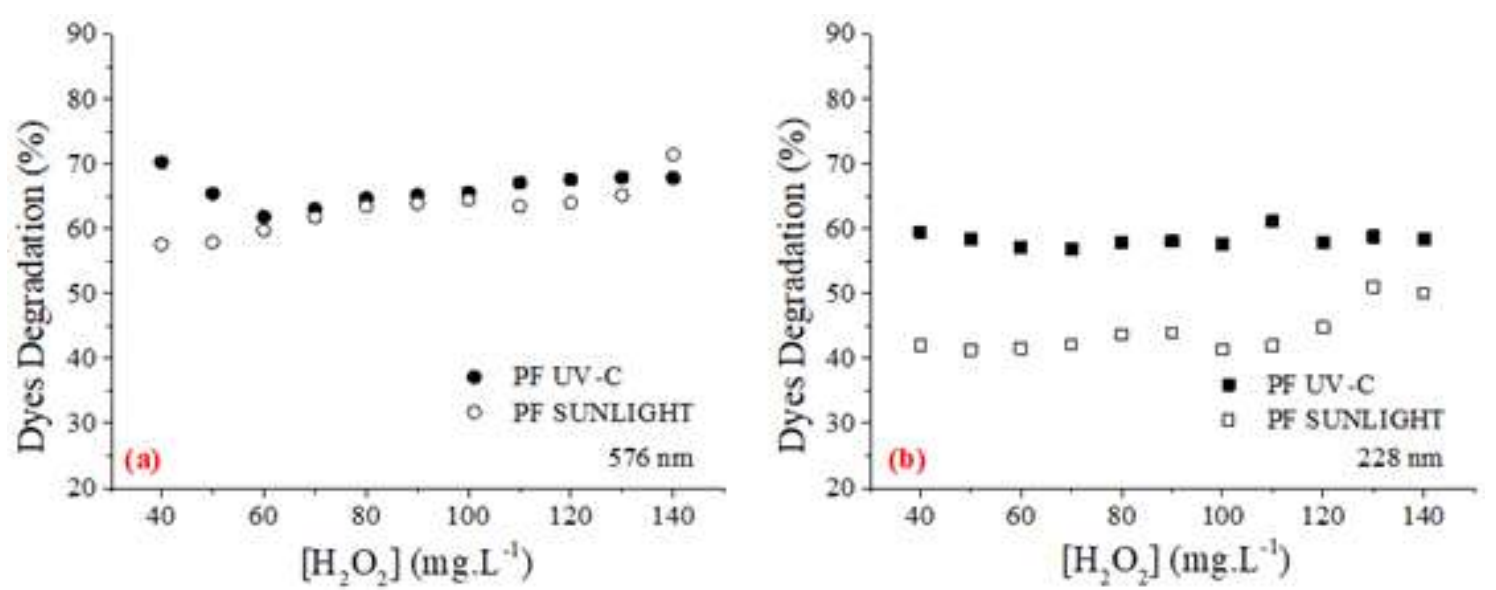

Source: Authors (2021) 
In Figure 3, it can be seen that at the $576 \mathrm{~nm}$, the lowest $\left[\mathrm{H}_{2} \mathrm{O}_{2}\right]\left(40 \mathrm{mg} \cdot \mathrm{L}^{-1}\right)$ showed the best result when applied under UV-C irradiation. Also, it demonstrates that an increase in the $\left[\mathrm{H}_{2} \mathrm{O}_{2}\right]$ does not favor the degradation of the compounds. For the $228 \mathrm{~nm}$, the highest degradation (61\%) was also observed at an $\left[\mathrm{H}_{2} \mathrm{O}_{2}\right]$ of $40 \mathrm{mg} \cdot \mathrm{L}^{-1}$.

The decrease in the efficiency of the treatment as the $\left[\mathrm{H}_{2} \mathrm{O}_{2}\right]$ is increased can explained since an excess of the oxidizing agent in the medium can lead to the hijack of hydroxyl radicals and the formation of superoxide radicals which decrease the efficiency of the process. The latter has a lower reduction potential $\left(E_{0}=+1.70 \mathrm{~V}\right)$ when compared to the $\mathrm{H}_{2} \mathrm{O}_{2}\left(\mathrm{E}_{0}=+2.80 \mathrm{~V}\right)$, justifying the lower degradation when there is an excess of hydrogen peroxide in the solution (Galeano et al., 2019; Gautam; Kumar; Lokhandwala, 2019).

In a study by Amorin, Leão, and Moreira (2009), when evaluating the influence of the $\left[\mathrm{H}_{2} \mathrm{O}_{2}\right]$ variation on the degradation of the reactive red azoic dye 195 by the photo-Fenton process with UV radiation, it was found that the decolorization speed is practically the same for concentrations of 40 to $100 \mathrm{mg} \cdot \mathrm{L}^{-1}$ of $\mathrm{H}_{2} \mathrm{O}_{2}$. Therefore, the authors recommend the use of $40 \mathrm{mg} \cdot \mathrm{L}^{-1}$ as the most convenient for the treatment, to reduce the operational costs.

While for the artificial solar irradiation, the highest $\left[\mathrm{H}_{2} \mathrm{O}_{2}\right]$ on this study $\left(140 \mathrm{mg} \cdot \mathrm{L}^{-1}\right)$ led to the best dye degradation results, reaching $71.9 \%$ at $576 \mathrm{~nm}$ and $51 \%$ at $228 \mathrm{~nm}$. This happens since the compounds present at the $228 \mathrm{~nm}$ wavelength have a greater need for absorbed energy (in addition to steric effects), therefore, to reach the same degradation range achieved using the UV-C radiation, a higher concentration of hydrogen peroxide is needed (Ertugay; Acar, 2017).

Thus, considering the highest degradation of the chromophore groups in the solution, the most efficient $\left[\mathrm{H}_{2} \mathrm{O}_{2}\right]$ for the UV-C $\left(40 \mathrm{mg} \cdot \mathrm{L}^{-1}\right)$ and artificial solar radiation $\left(140 \mathrm{mg} \cdot \mathrm{L}^{-1}\right)$ were fixed and then the effect of the [Fe] variation during the treatment of the solutions under study was evaluated. The results obtained are shown in Figure 4. 
Figure 4 - Influence of the [Fe] variation on the efficiency of the photo-Fenton (PF) process under UV-C and sunlight radiation, for $\lambda$ : a) 576 and b) $228 \mathrm{~nm}$

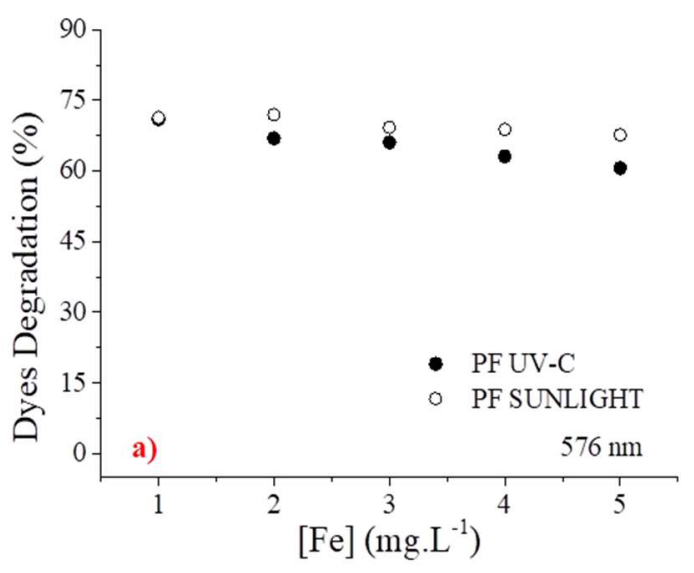

$[\mathrm{Fe}]\left(\mathrm{mg} . \mathrm{L}^{-1}\right)$

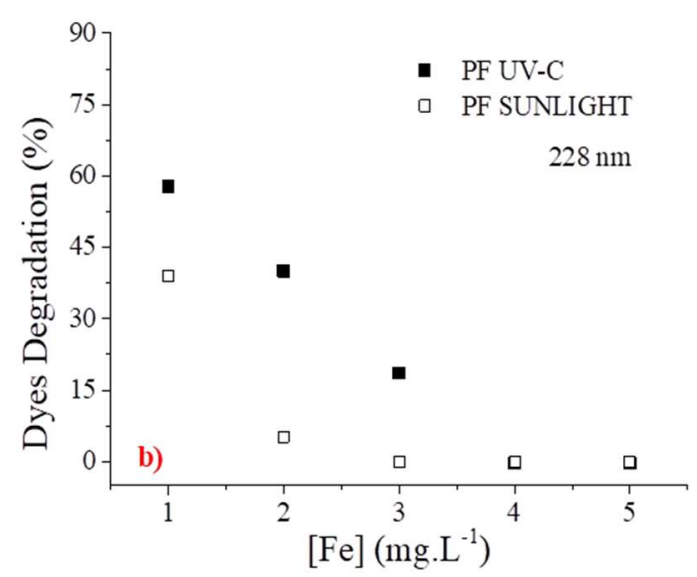

Source: Authors (2021)

From Figure 4, it can be seen that in the $576 \mathrm{~nm}$ (chromophores), the lower the [Fe] used in the treatment the greater the efficiency of the photo-Fenton process, reaching $71 \%$ degradation for both radiations. Similar results were observed for the aromatic groups (228 $\mathrm{nm})$, with a greater efficiency also being observed when applying an [Fe] of $1 \mathrm{mg} \cdot \mathrm{L}^{-1}$ for both UV-C (57.8\%) and artificial solar (39\%) radiations.

However, the presence of iron above $2 \mathrm{mg} \cdot \mathrm{L}^{-1}$ caused inefficiency in the treatment of the aromatic groups present in the treated solution, for both radiations. This behavior can be explained by the role of the iron in the photo-Fenton reaction. The ferrous ions act on the decomposition of the hydrogen peroxide in the treated medium, producing hydroxyl radicals and ferric ions. These $\mathrm{Fe}^{3+}$ ions form complex and recalcitrant intermediates, regenerating the $\mathrm{Fe}^{2+}$ ion and favoring the autoinhibition of the hydroxyl radical $(\cdot \mathrm{OH})$. Therefore, if the $[\mathrm{Fe}]$ is above ideal, the probability that this inhibitory reaction will occur increases, which can lead to a decrease in the rate of degradation of the chromophores and aromatics groups (Bensalah; Dbira; Bedoui, 2019; Dewil et al., 2017).

With the results obtained, the $\mathrm{pH}$ influence was analyzed, by keeping the $\left[\mathrm{H}_{2} \mathrm{O}_{2}\right]$ at 40 $\mathrm{mg} \cdot \mathrm{L}^{-1}$ for the UV-C radiation and at $140 \mathrm{mg} \cdot \mathrm{L}^{-1}$ for the artificial solar radiation, while the $[\mathrm{Fe}]$ 
was fixed at $1 \mathrm{mg} \cdot \mathrm{L}^{-1}$ for both situations. The degradation results obtained are shown in Figure 5.

Figure 5 - Influence of the $\mathrm{pH}$ variation of the efficiency of the photo-Fenton (PF) process under UV-C and sunlight radiation, for the $\lambda$ of $576 \mathrm{~nm}(\mathrm{a})$ and $228 \mathrm{~nm}(\mathrm{~b})$

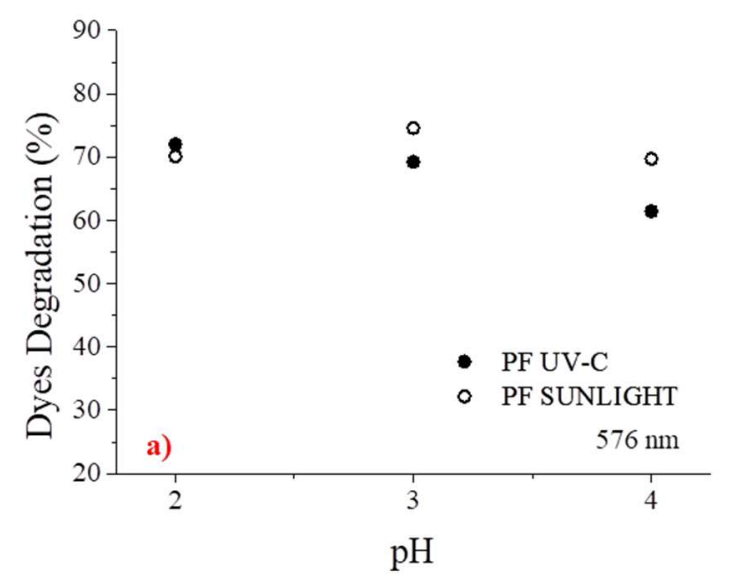

Source: Authors (2021)

From Figure 5 it can be seen that at the wavelength of $576 \mathrm{~nm}$ a greater treatment efficiency is obtained at $\mathrm{pH}$ values below 4 for both radiations. Then, it was identified that the ideal $\mathrm{pH}$ for this process was equal to 3 on the artificial solar radiation (74.6\%) and 2 for the UV-C (72.1\%). When evaluating the degradation of aromatics, the best treatment was conducted at $\mathrm{pH} 4$ for both radiations, with degradations of $56 \%$ for the artificial solar radiation and $65 \%$ for the UV-C radiation.

According to Torrades and García-Montaño (2014), pH values above 4 favor a phenomenon that is known as iron sludge, characterized by the precipitation of ferric oxyhydroxide, an aqueous iron complex formed during the treatment. Such compounds are insoluble at $\mathrm{pH}$ higher than the one studied, indicating that the Fenton and photo-Fenton processes show better results when conducted at pH between 2.5 and 3.0 (maximum catalytic activity around $\mathrm{pH}=2.8$ ). Thus, the values of degradation in this treatment would be influenced by this phenomenon, since the supernatant from the precipitation interferes in the quantification, not effectively representing how much has been degraded. 
In this way, the $\mathrm{pH}$ was fixed at 3 for the treatment with artificial solar radiation and at 2 for UV-C, maintaining $\left[\mathrm{H}_{2} \mathrm{O}_{2}\right]$ at $140 \mathrm{mg} \cdot \mathrm{L}^{-1}$ and $40 \mathrm{mg} \cdot \mathrm{L}^{-1}$ respectively, and fixing [Fe] at $1 \mathrm{mg} \cdot \mathrm{L}^{-1}$. Then the effect of the volume of the solution to be treated was also evaluated (Figure 6).

Figure 6 - Influence of the volume variation on the efficiency of the photo-Fenton (PF) under UV-C and sunlight radiation, for the $\lambda$ of 576 (a) and $228 \mathrm{~nm}$ (b)

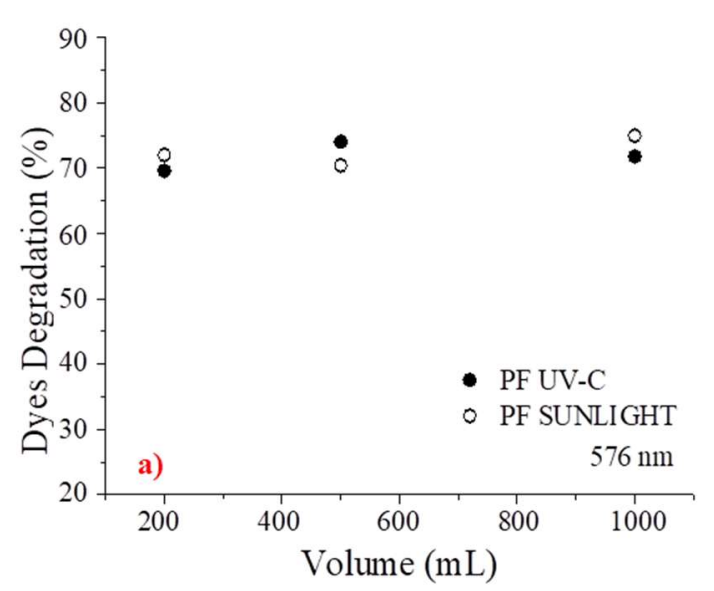

Source: Authors (2021)

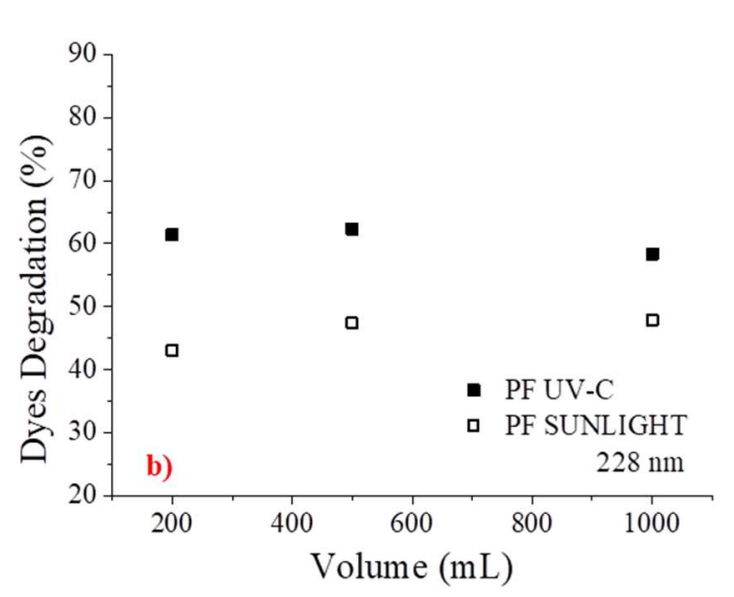

As shown in Figure 6, the results of dye degradation for the $576 \mathrm{~nm} \lambda$ were between $70-75 \%$ for both radiations, while for the $228 \mathrm{~nm} \lambda$, it was between $43-48 \%$ for the artificial solar radiation and $58-62 \%$ for the UV-C radiation. These results showed that the influence of the solution volume on the degradation process is quite small and that the experimental conditions defined in the previous studies can be applied to different volumes. Based on this, to evaluate the process kinetics, a larger solution volume could be used without a significant loss of treatment efficiency.

\subsection{Kinetic monitoring}

The kinetic study followed the degradation of the chromophores and aromatics groups for the photo-Fenton process with UV-C and sunlight radiation $(1000 \mathrm{ml}$ of the dye mixture solution; $\left[\mathrm{H}_{2} \mathrm{O}_{2}\right]=40 \mathrm{mg} \cdot \mathrm{L}^{-1} ;[\mathrm{Fe}]=2 \mathrm{mg} \cdot \mathrm{L}^{-1} \mathrm{e} \mathrm{pH}=2$ ). This study was conducted from 
different initial dye concentrations, at a temperature of $29 \pm 1^{\circ} \mathrm{C}, \mathrm{p}=1$ atm and $\mathrm{t}=360$ min, with the kinetic curves shown in Figure 7 , for both $\lambda$.

Figure 7 - Effect of the initial concentration of the dye solution on the efficiency of the photo-Fenton process, radiation and $\lambda$ : a) UV-C / $576 \mathrm{~nm}$; b) UV-C / $228 \mathrm{~nm}$; c) sunlight / $576 \mathrm{~nm}$; d) sunlight / $228 \mathrm{~nm}$
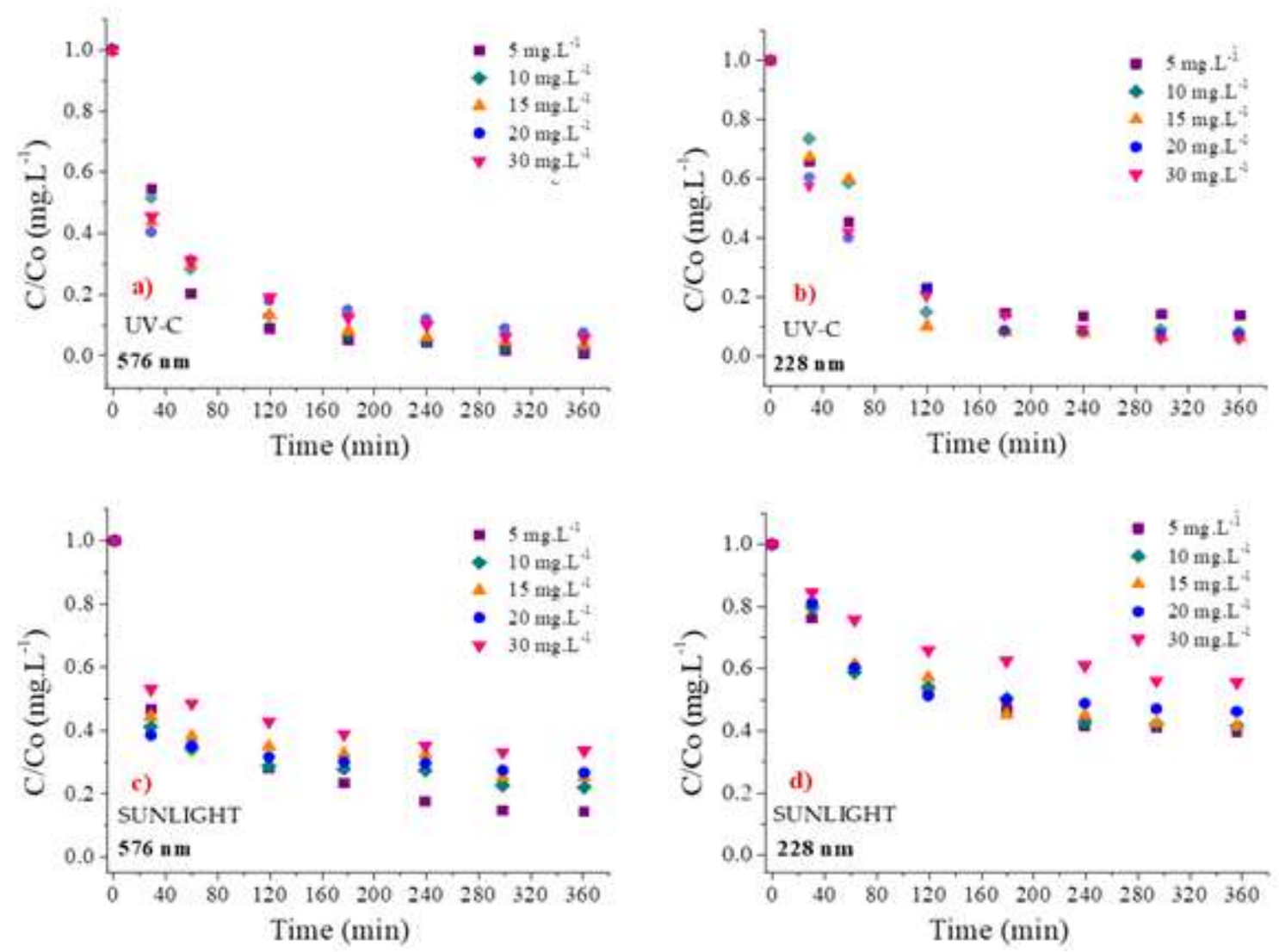

Source: Authors (2021)

Analyzing Figure 7, for the $576 \mathrm{~nm}$ wavelength, in the UV-C radiation, the kinetic behavior is similar after $120 \mathrm{~min}$, for all initial concentrations evaluated. Showing that the photo-Fenton/UV-C system is efficient to treat the dye mixture in a range of 5 to $30 \mathrm{mg} \cdot \mathrm{L}^{-1}$ after the variables are optimized.

Concerning the $228 \mathrm{~nm}$ wavelength, a degradation of $85 \%$ is reached after 180 minutes of treatment. Through Figure 7 it can be verified that the major portion of the 
chromophore degradation (> 70\%) occurred in the first 60 min of reaction, reaching values greater than $92 \%$ at the end of the treatment time.

Figure 7 also shown that under sunlight radiation, the aromatic groups had a degradation above $35 \%$ after $120 \mathrm{~min}$ in all analyzed concentrations, reaching more than $60 \%$ degradation at the end of the treatment. Also, after 240 min of reaction, no significant difference in the degradation was detected for the $228 \mathrm{~nm}$ wavelength.

Comparing the data from the two radiations applied with the AOP (Figure 7), it is verified a lower degradation under sunlight radiation for both evaluated wavelengths. This can be explained by the fact that the solar spectrum has a greater intensity in the visible region and a lower energy capacity (Pouran; Aziz; Daud, 2015).

Then, it was evaluated the suitability of different kinetic models to the experimental data obtained, to better observe the behavior of the dye mixture treatment under AOP, as can be seen in the kinetic curve shown in Figure 8 .

Figure 8 - Kinetic adjustment to Chan and Chu, first order and second order models for the photo-Fenton process, with [dyes] $=20 \mathrm{mg} \cdot \mathrm{L}^{-1}$, radiation $/ \lambda$ : a) UV-C / $576 \mathrm{~nm}$; b) UV-C / $228 \mathrm{~nm}$; c) sunlight / $576 \mathrm{~nm}$; d) sunlight $/ 228 \mathrm{~nm}$. Conditions: $\left[\mathrm{H}_{2} \mathrm{O}_{2}\right]=40 \mathrm{mg} \cdot \mathrm{L}^{-1},[\mathrm{Fe}]=1$ $\mathrm{mg} \cdot \mathrm{L}^{-1}$ and $\mathrm{pH}=2, \mathrm{~T}=29 \pm 1^{\circ} \mathrm{C}, \mathrm{p}=1 \mathrm{~atm}$
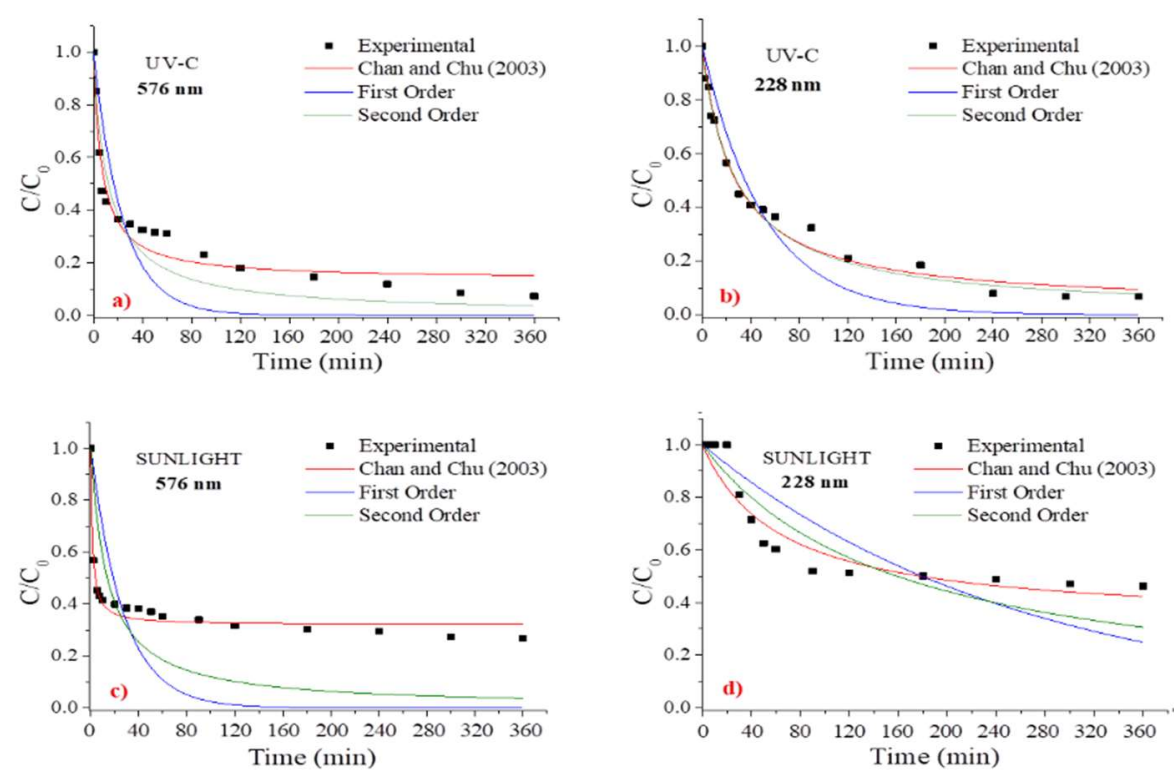
Given the results presented in Figure 8, it appears that, in general, the degradation process via the photo-Fenton AOP for both wavelength and radiations studied has a fast stage in the first $30 \mathrm{~min}$ of the process, followed by a slow stage until the $180 \mathrm{~min}$ and then the treatment stabilization until the 360 min evaluated. Regarding the adjustments, the nonlinear model proposed by Chan and Chu (2003) proved to be adequate for describing the degradation data, considering the cases evaluated. This model presented values of $R^{2}$ varying between 0.95 and 0.98 under the UV-C radiation and between 0.91 and 0.97 for the sunlight radiation.

Evaluating the Chan and Chu model, as shown in Figure 8, the concentration decay rate $(1 / p)$ for the aromatic groups was 0.037 and $0.011 \mathrm{~min}^{-1}$ respectively for the UV-C and sunlight radiations, and $0.126 \mathrm{~min}^{-1}$ and $0.506 \mathrm{~min}^{-1}$ for the chromophores, also in that order. This decay was more accentuated at the $576 \mathrm{~nm}$, since the higher the value of $1 / \mathrm{p}$, the faster the contamination concentration decreases. However, under the UV-C irradiation, the maximum oxidative capacity $(1 / \sigma)$ in the aromatic $(0.970)$ and chromophore $(0.865)$ groups is higher than that presented by the sunlight radiation, with both groups with the same value for this parameter, 0.68 . Demonstrating that the use of sunlight radiation leads to a lower oxidation of the dye.

Thus, it is noticeable that the PF process employing UV-C radiation is the most viable among the evaluated AOPs, with this process being selected to proceed with the final analyzes of the work. This process was also suggested by Santana and collaborators (2018) for the degradation of direct orange dye 26. According to the authors, the use of AOPs allows the degradation of organic compounds and the removal of toxicity from aqueous matrices, with the possibility of adding these processes as a post-treatment in wastewater treatment plants.

However, the authors reaffirmed the need for a toxicological assessment for the proposed treatment, to verify if there is no formation of toxic intermediates or products, which could lead to an increase of the environmental risks. 


\subsubsection{Toxicity assessment}

Toxicity assays were carried out under the same conditions used for the kinetic monitoring, being used in the tests seeds of lettuce (Lactuca sativa), carrot (Daucus carota subsp. sativus), arugula (Eruca vesicaria ssp. sativa), and watercress (Nasturtium officinale). The evaluation was carried out using values of the germination (GI) and relative growth (RGI) indexes, comparing the results obtained in the negative control with the solutions before and after treatment by the photo-Fenton UV-C process (Table 1). It should be noted that there was no germination of the seeds exposed to the boric acid solution.

Table 1 - GI (\%) and RGI values for the textile dye mixture (direct black 22; acid black 172 and reactive black 5) solution before and after treatment by the photo-Fenton

process (triplicate analysis)

\begin{tabular}{ccccccccc}
\hline \multirow{2}{*}{ Sample } & \multicolumn{2}{c}{$\begin{array}{c}\text { Lactuca } \\
\text { sativa }\end{array}$} & \multicolumn{2}{c}{$\begin{array}{c}\text { Daucus } \\
\text { carota }\end{array}$} & \multicolumn{2}{c}{ Eruca vesicaria } & \multicolumn{2}{c}{$\begin{array}{c}\text { Nasturtium } \\
\text { officinale }\end{array}$} \\
\cline { 2 - 9 } & RGI & GI (\%) & RGI & GI (\%) & RGI & GI (\%) & RGI & GI (\%) \\
\hline $\begin{array}{c}\text { Water } \\
(\text { NC) }\end{array}$ & 1.00 & 100.00 & 1.00 & 100.00 & 1.00 & 100.00 & 1.00 & 100.00 \\
\hline SBT & 1.45 & 162.96 & 1.91 & 158.28 & 1.74 & 189.04 & 1.54 & $178.75-$ \\
\hline $\begin{array}{c}\text { Photo- } \\
\text { Fenton } \\
\text { UV-C }\end{array}$ & 0.83 & 89.79 & 0.80 & 69.89 & 0.93 & 98.58 & 0.85 & 78.40 \\
\hline
\end{tabular}

Source: Authors (2021)

Legend: NC - negative control

From Table 1, it can be seen that the before-treatment solution showed growth and germination above the negative control. This behavior can be explained by the presence of nitrogen groups in the constitution of the textile dyes present in the aqueous solution, which can act as a source of nutrients for the development of the seeds. Based on the classification proposed by Young et al. (2012), all types of seeds exposed to the solution before treatment suffered stimulation of root elongation $(R G I>1.2)$, while the seeds exposed to the solution after treatment did not show significant effects of toxicity $(0.8 \leq R G I \leq 1.2)$, although they showed lower values than the control. 
Nascimento et al. (2020) evaluated the toxicity of the mixture of tartrazine yellow and sunset yellow food dyes before and after treatment with the photo-Fenton/UV-C AOP using seeds of the Lactuca sativa species. The authors found a reduction in the toxicity of the aftertreatment solution using the photo-Fenton process. Thus, it appears that after the AOP treatment applied in this work, it was obtained a treated solution without toxic effects, which was not evidenced for the solution before the treatment.

\subsection{Artificial Neural Network}

Verified the efficiency of the photo-Fenton/UV-C process to degrade the dye mixture solution, a mathematical evaluation was performed using artificial neural networks (ANN). The descriptive statistics of the variables used in the ANN are shown in Table 2.

Table 2 - Descriptive statistics of the variables used in the ANN

\begin{tabular}{|c|c|c|c|c|c|c|c|}
\hline $\begin{array}{c}\text { Variables/ } \\
\text { samples }\end{array}$ & $\begin{array}{c}\text { [Dye] } \\
\left(\mathrm{mg} \cdot \mathrm{L}^{-1}\right)\end{array}$ & $\begin{array}{l}\text { Time } \\
\text { (min) }\end{array}$ & $\begin{array}{c}\mathrm{H}_{2} \mathrm{O}_{2} \\
\left(\mathrm{mg} \cdot \mathrm{L}^{-1}\right)\end{array}$ & $\begin{array}{c}{[\mathrm{Fe}]} \\
\left(\mathrm{mg} \cdot \mathrm{L}^{-1}\right)\end{array}$ & pH & $\begin{array}{c}\text { (576nm) } \\
*\end{array}$ & $\begin{array}{c}(228 \mathrm{~nm}) \\
*\end{array}$ \\
\hline Min (Train) & 5.00 & 2.00 & 0.00 & 0.00 & 2.00 & 14.85 & -19.33 \\
\hline Max (Train) & 20.0 & 360.00 & 140.00 & 5.00 & 6.00 & 100.00 & 93.63 \\
\hline Mean (Train) & 18.91 & 94.26 & 52.46 & 1.19 & 2.57 & 66.95 & 54.84 \\
\hline SD (Train) & 3.33 & 88.58 & 29.79 & 0.97 & 0.90 & 15.71 & 24.14 \\
\hline Min (Test) & 5.00 & 2.00 & 0.00 & 0.00 & 2.00 & 14.85 & -19.33 \\
\hline Max (Test) & 20.00 & 360.00 & 140.00 & 5.00 & 6.00 & 100.00 & 93.55 \\
\hline Mean (Test) & 18.45 & 95.46 & 47.16 & 1.18 & 2.51 & 67.40 & 54.62 \\
\hline SD (Test) & 4.15 & 86.59 & 26.84 & 1.01 & 0.76 & 17.61 & 25.02 \\
\hline $\begin{array}{c}\text { Min } \\
\text { (Validation) }\end{array}$ & 5.00 & 2.00 & 0.00 & 0.00 & 2.00 & 22.45 & -19.33 \\
\hline $\begin{array}{c}\text { Max } \\
\text { (Validation) }\end{array}$ & 20.00 & 360.00 & 140.00 & 5.00 & 6.00 & 101.00 & 92.56 \\
\hline $\begin{array}{c}\text { Mean } \\
\text { (Validation) }\end{array}$ & 18.88 & 89.49 & 48.64 & 1.20 & 2.45 & 68.75 & 54.91 \\
\hline $\begin{array}{c}\text { SD } \\
\text { (Validation) }\end{array}$ & 1.11 & 29.67 & 42.48 & 1.46 & 1.20 & 15.61 & 22.63 \\
\hline
\end{tabular}


Through the analysis of Table 2, it was predicted that a maximum degradation of the dye mixture equal to $100 \%$ for the $576 \mathrm{~nm}$ and $93.5 \%$ for the $228 \mathrm{~nm}$ could be achieved. The optimization of the ANN topology is a very important step in the development of the model so that in this work a three-layer posterior propagation neural network (5:6:2, with training algorithm BFGS 180 was used for modeling the degradation of the mixture of textile dyes DB22, AB172 and RB5, whose architecture diagram is shown in Figure 9.

Figure 9 - ANN architecture diagram MLP 5-6-2 BFGS 180

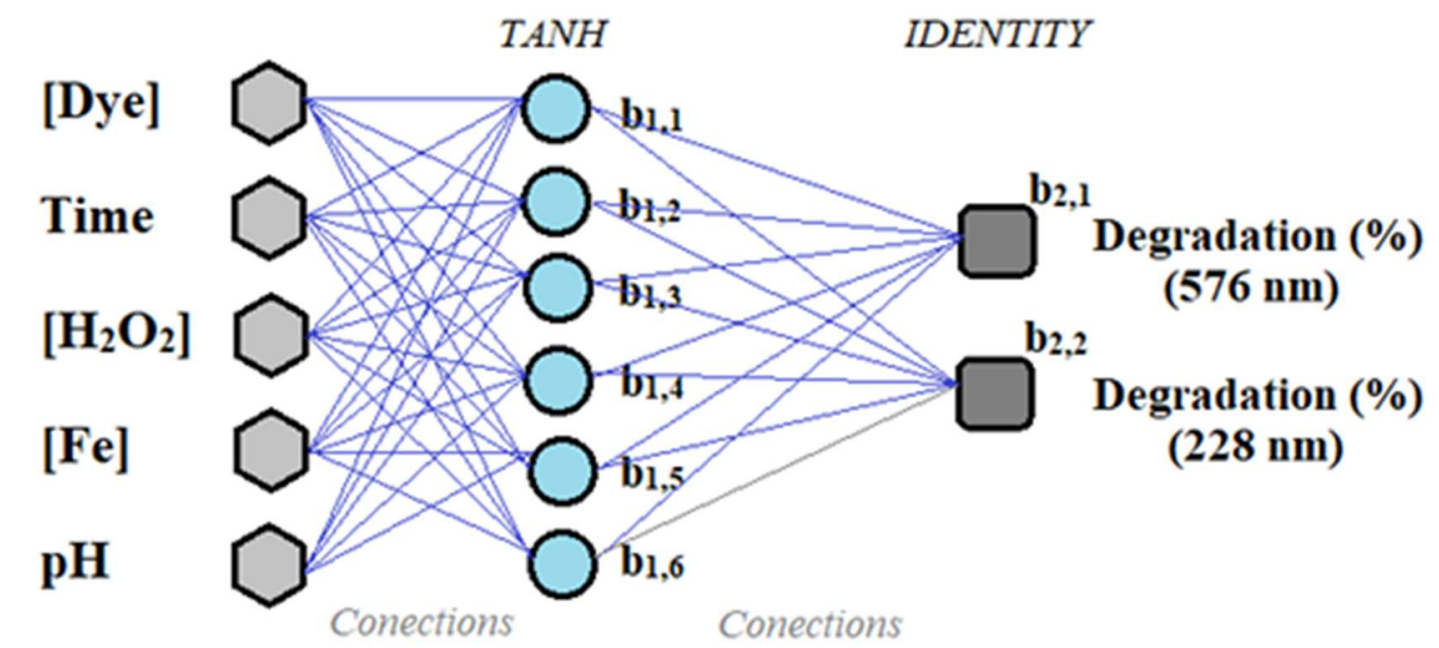

Input layer Intermediate layer Output layer

Source: Authors (2021)

In Figure 9, it is possible to observe that the tanh and identity activation functions were used for the input and output layers, respectively. The mentioned ANN showed R2 values equal to $0.949 ; 0.952$ and 0.956 for training, testing, and validation, respectively. Then, training, validation, and test errors were evaluated on an inverse interval scale to return the predicted responses to their original scale, and then compared with the experimental responses, obtaining the weights listed in Table 3. 
Table 3 - Weight values for the ANN MLP 5-6-2 (BFGS 180, Tanh- Identity) input, intermediate and output layers

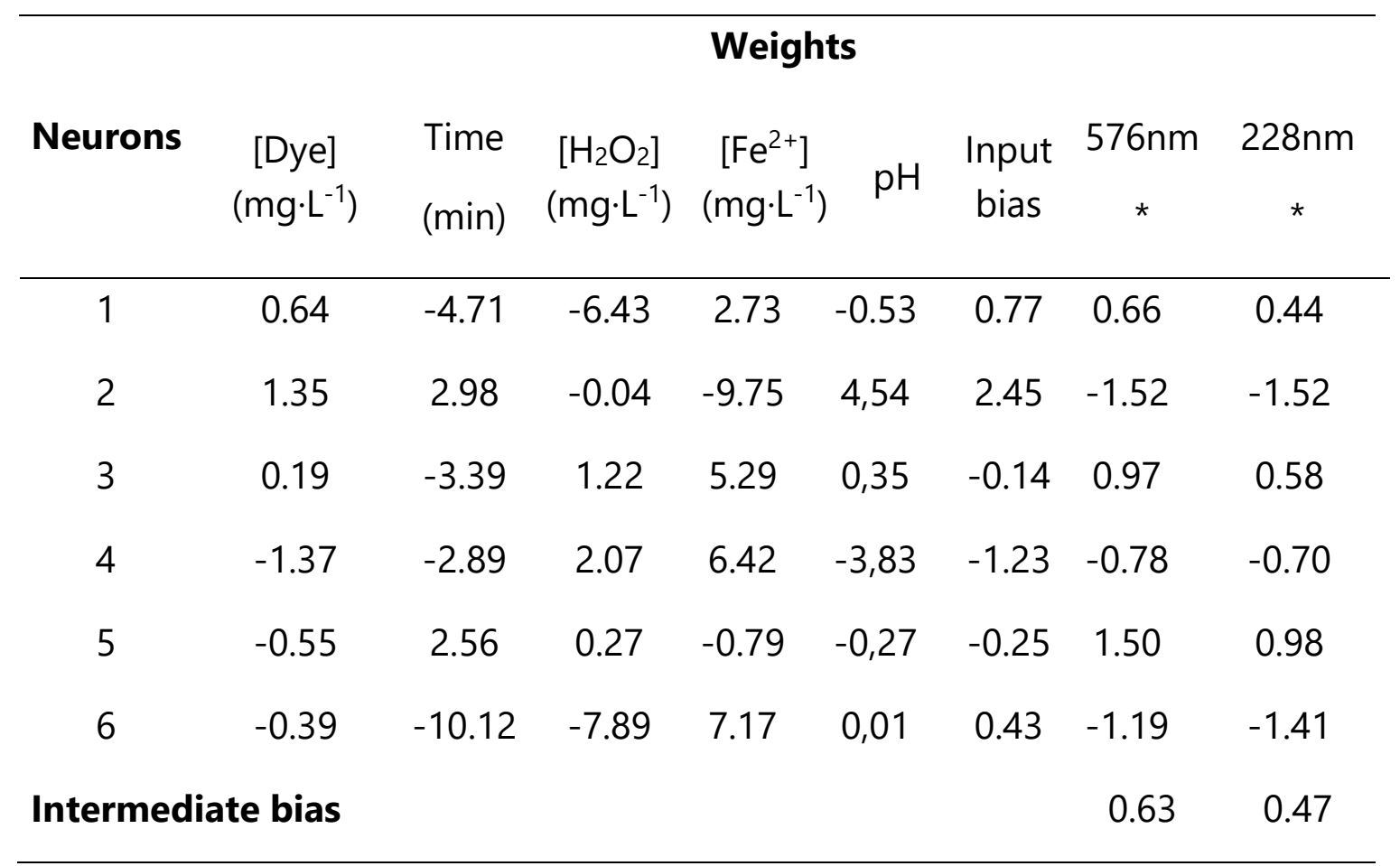

Source: Authors (2021)

* Degradation (\%)

The weights shown in Table 3 refer to what proportion of the received signal will be transmitted to the neuron's body. Then, the experimental results were compared with the simulated results, using linear regression graphs (Figure 10).

(Continue...) 
Figure 10 - Linear regressions between the experimental and simulated results of the MLP ANN (BFGS 180) for the wavelengths of: a) $576 \mathrm{~nm}$ and b) $228 \mathrm{~nm}$
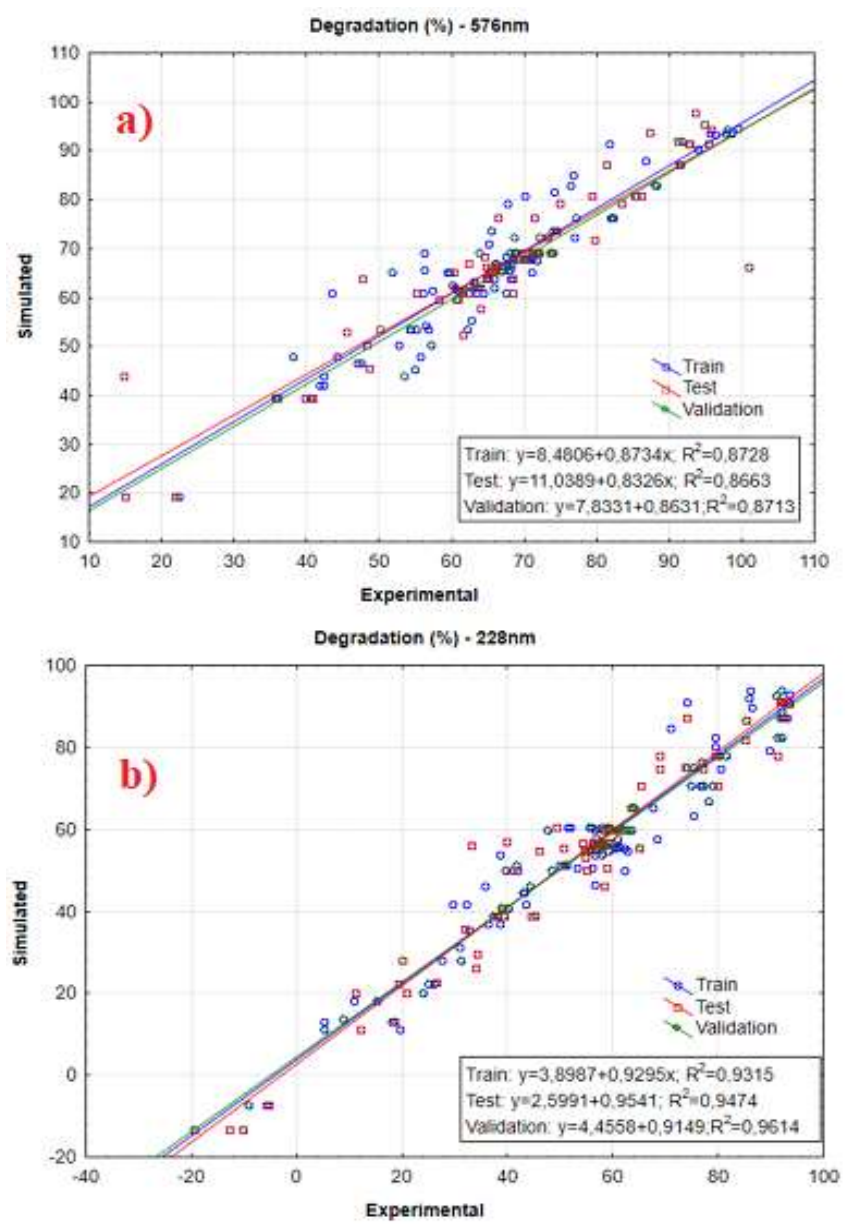

Source: Authors (2021)

In Figure 10, it is possible to verify that the experimental results are around the linear regression lines, indicating a good reproduction of the ANN MLP 5-6-2 (BFGS 180) for test, training, and validation sets. The graphs show the correlation coefficients confirming that the model reproduces the degradation of the compounds in these systems with $R^{2}>0.86$, within the experimental ranges adopted in the assembly model, especially for aromatic groups, where $\mathrm{R}^{2}>0.93$.

Using an artificial neural network, Durán, Monteagudo, and Mohedano (2006) predicted the maximum degradation that could be achieved in the reactive dye solution Blue 4 (RB4) using the photo-Fenton/UV-C AOP. Through the input variables (initial 
concentrations of $\mathrm{RB} 4, \mathrm{H}_{2} \mathrm{O}_{2}, \mathrm{Fe}(\mathrm{II}), \mathrm{pH}$, and temperature) it was possible to know the influence exerted on the kinetic constants of discoloration and mineralization, predicting the total elimination of RB4 after the initial 30 min of the reaction.

\section{CONCLUSIONS}

From the results obtained, it was verified the feasibility of applying the photo-Fenton process under UV-C radiation to degrade the mixture of the dyes DB22, AB172, and RB5. It was possible to promote the degradation not only of the chromophore groups (92.8\%) but also of the aromatics (93.2\%). Also, it was found that the color removal is faster in the first minutes, however, the aromatic groups are more easily degraded at the end of the treatment. Thus, according to the evaluation of the reaction kinetics, it was verified that the non-linear pseudo-first-order model described by Chan and Chu (2003) is more suitable for describing the degradation data of the studied process. In this context, it was found through toxicity studies with lettuce (Lactuca sativa), carrots (Daucus carota subsp. Sativus), arugula (Eruca vesicaria ssp. Sativa), and watercress (Nasturtium officinale) seeds that after the treatment non-toxic solutions were obtained, proving that the process is beneficial and applicable for removing the pollutants without causing greater risk to the aquatic environment. The maximum degradation efficiency of the dye mixture concerning the photo-Fenton/UV-C process was evaluated through an artificial neural network (ANN), it predicted a total degradation of the groups presents in the $576 \mathrm{~nm}$ and $93.5 \%$ for the $228 \mathrm{~nm}$, thus verifying the efficiency of the treatment for the studied dyes.

\section{ACKNOWLEDGMENTS}

For Núcleo de Química Analítica Avançada de Pernambuco - NUQAAPE (FACEPE, processo APQ-0346-1.06/14), FADE/UFPE, FACEPE and EXATACOR. 


\section{REFERENCES}

ABIT (2019) Associação Brasileira da Indústria Têxtil e de Confecções. Perfil do setor <http://www.abit.org.br/cont/perfil-do-setor>

ADAK, A.; MANGALGIRI, K. P.; LEE, J.; BLANEY, L. UV irradiation and UV- $\mathrm{H}_{2} \mathrm{O}_{2}$ advanced oxidation of the roxarsone and nitarsone organoarsenicals. Water Res, v. 70, p. 74-85, 2015.

AL-MAMUN, M. R.; KADER, S.; ISLAM, M. S.; KHAN, M. Z. H. Photocatalytic activity improvement and application of UV- $\mathrm{TiO}_{2}$ photocatalysis in textile wastewater treatment: A review. J. Environ. Chem. Eng., v. 7, n. 5, p. 103248, 2019.

ALMOMANI, F.; TOURAUD, E.; DEGORCE-DUMAS, J. R.; ROUSSY, J.; THOMAS, O. Biodegradability enhancement of textile dyes and textile wastewater by VUV photolysis. J Photoch Photobio A, v. 153, n. 3, p. 191-197, 2002.

AMORIM, C. C.; LEÃO, M. M. D.; MOREIRA, R. F. P. M. Comparação entre diferentes processos oxidativos avançados para degradação de corante azo. Eng. Sanit. Ambient., v. 14, n. 4, p. 543-550, 2009.

AQUINO, R. V. S.; BARBOSA, A. A.; RIBEIRO, L. B.; OLIVEIRA, A. F. B.; SILVA, J. P.; AZOUBEL, P. M.; ROCHA, O. R. S. Degradation of leaf green food dye by heterogeneous photocatalysis with TiO2 over a polyethylene terephthalate plate. Chem Pap, v. 73, n. 10, p. 2501-2512, 2019.

BENSALAH, N.; DBIRA, S.; BEDOUI, A. Mechanistic and kinetic studies of the degradation of diethyl phthalate (DEP) by homogeneous and heterogeneous Fenton oxidation. Environ. Nanotechnol. Monit. Manag., v. 11: p. 100224, 2019.

BOUR, A.; MOUCHET, F.; SILVESTRE, J.; GAUTHIER, L.; PINELLI, E. Environmentally relevant approaches to assess nanoparticles ecotoxicity: A review. J. Hazard. Mater., v. 283, p. 764-777, 2015.

CHAN, K. H.; CHU, W. Modeling the reaction kinetics of Fenton's process on the removal of atrazine. Chemosphere, v. 51, n. 4, p. 305-311, 2003.

CHANGOTRA, R.; RAJPUT, H.; DHIR, A. Treatment of real pharmaceutical wastewater using combined approach of Fenton applications and aerobic biological treatment. J Photoch Photobio A, v. 376, p. 175-184, 2019.

CHU, W.; TSUI, S. M. Modeling of photodecoloration of azo dye in a cocktail photolysis system. Water Res, v. 36, n. 13, p. 3350-3358, 2002.

DEWIL, R.; MANTZAVINOS, D.; POULIOS, I.; RODRIGO, M. A. New perspectives for Advanced Oxidation Processes. J. Environ. Manag., v. 195(pt.2), p. 93-99, 2017. 
DIAS, F. F. S.; CHIAVONE-FILHO, O.; LIRA, R. M.; CARVALHO, F. O.; PACHECO, J. G. Degradação de corante Reative Black 5 via processo foto-Fenton em reator PTC com modelagem e otimização utilizando RNA. Sci. Plena, v. 9, n. 10, p. 104201, 2013.

DIAS, F. F. S.; SILVA, P. B. V.; SANTOS, A. F. M. S.; ANDRADE, J. G.; ALBUQUERQUE, I. L. Tratamento de efluente têxtil através de processo oxidativo avançado $\left(\mathrm{H}_{2} \mathrm{O}_{2} / \mathrm{TiO}_{2} / \mathrm{UV}\right)$. Revista Geama, v. 4, n. 3, p. 4-9, 2018.

DURÁN, A.; MONTEAGUDO, J. M.; MOHEDANO, M. Neural networks simulation of photo-Fenton degradation of Reactive Blue 4. Appl. Catal. B, v. 65 n. 2, p. 127-134, 2006.

ERTUGAY, N.; ACAR, F. N. Removal of COD and color from Direct Blue 71 azo dye wastewater by Fenton's oxidation: Kinetic study. Arab. J. Chem., v. 51, n. 1, 2013.

FERREIRA, S. A. D.; DONADIA, J. F.; GONÇALVES, G. R.; TEIXEIRA, A. L.; FREITAS, M. B. J. G.; FERNANDES, A. A. R.; LELIS, M. F. F. Photocatalytic performance of granite waste in the decolorization and degradation of Reactive Orange 122. J. Environ. Chem. Eng., v. 7, n. 3, p. 103144, 2019.

FIOREZE, M.; SANTOS, E. P.; SCHMACHTENBERG, N. Processos oxidativos avançados: fundamentos e aplicação ambiental. REGET, v. 18, n. 1, p. 79-91, 2014.

GALEANO, L. A.; GUERRERO-FLÓREZ, M.; SÁNCHEZ, C. A.; GIL, A.; VICENTE, M. Á. Disinfection by chemical oxidation methods, Springer, v. 67, p. 257-295, 2019.

GARCIA, V. S. G.; ROSA, J. M.; BORRELY, S. I. Toxicity and color reduction of a textile effluent containing reactive red 239 dye by electron beam irradiation. Radiat Phys Chem, v. 172, p. 108765, 2020.

GAUTAM, P.; KUMAR, S.; LOKHANDWALA, S. Advanced oxidation processes for treatment of leachate from hazardous waste landfill: a critical review. J. Clean. Prod., v. 237, p. 117639.

GIANNAKIS, S. A review of the concepts, recent advances and niche applications of the (photo) Fenton process, beyond water/wastewater treatment: Surface functionalization, biomass treatment, combatting cancer and other medical uses. Appl. Catal. B, v. 248, n. 5, p. 309-319, 2019.

HITAM, C. N. C.; JALIL, A. A. A review on exploration of $\mathrm{Fe}_{2} \mathrm{O}_{3}$ photocatalyst towards degradation of dyes and organic contaminants. J. Environ. Manage., v. 258, p. 110050, 2020.

HOLKAR, C. R.; JADHAV, A. J.; PINJARI, D. V.; MAHAMUNI, N. M.; PANDIT, A. B. A critical review on textile wastewater treatments: Possible approaches. J. Environ. Manage., v. 182, p. 351-366, 2016.

HOSSAIN, L.; SARKER, S. K.; KHAN, M. S. Evaluation of present and future wastewater impacts of textile dyeing industries in Bangladesh. Environ. Dev, v. 26, p. 23-33, 2018.

HUANG, T.; YAN, L.; ZHENG, S.; WANG, X.; FAN, L.; LI, C.; ZHAO, Y.; MARTYNIUK, C. Discriminating modes of toxic action in mice using toxicity in BALB/c mouse fibroblast (3T3) cells. Chemosphere, v. 188, p. 73-80, 2017. 
KHUZWAYO, Z.; CHIRWA, E. M. N. Analysis of catalyst photo-oxidation selectivity in the degradation of polyorganochlorinated pollutants in batch systems using UV and UV/TiO 2 . S. Afr. J. Chem. Eng., $v$. 23, n. 17, 2017.

KUMAR, J. E.; MULAI, T.; KHARMAWPHLANG, W.; SHARAN, R. N.; SAHOO, M. K. Decolourisation, mineralisation and detoxification of mixture of azo dyes using Fenton and Fenton-type advanced oxidation processes. Chem Pap, v. 74, n. 9, p. 3145-3159, 2020.

LIANG, J.; NING, X.; SUN, J.; SONG, J.; LU, J.; CAI, H.; HONG, Y. Toxicity evaluation of textile dyeing effluent and its possible relationship with chemical oxygen demand. Ecotoxicol Environ Safe, v. 166, p. 56-62, 2018.

MARTINS, L. M.; SILVA, C. E.; NEYO, J. M. M.; LIMA, A. S.; MOREIRA, R. F. P. M. Aplicação de Fenton, foto-Fenton e $\mathrm{H} 2 \mathrm{O} 2$ no tratamento de efluente têxtil sintético contendo o corante preto biozol UC. Eng Sanit Ambient, v. 16, n. 3, p. 261-270, 2011.

MIKLOS, D. B.; REMY, C.; JEKEL, M.; LINDEN, K. G.; DREWES, J. E. Evaluation of advanced oxidation processes for water and wastewater treatment - A critical review. Water Res, v. 139, p. 118-131, 2018.

MONTEIRO, R. T.; SANTANA, R. M. R.; SILVA, A. M. R. B.; LUCENA, A. L. A.; ZAIDAN, L. E. M. C.; SILVA, V. L.; NAPOLEÃO, D. C. Degradation of the pharmaceuticals nimesulide and ibuprofen using photoFenton process: toxicity studies, kinetic modeling and use of artificial neural networks. REGET, v. 22, p. 01-21, 2018.

MORAES, N.; SANTANA, R.; GOMES, R.; JÚNIOR, S.; LUCENA, A.; ZAIDAN, L.; NAPOLEÃO, D. Performance verification of different advanced oxidation processes in the degradation of the dye acid violet 17: reaction kinetics, toxicity and degradation prediction by artificial neural networks. Chem Pap, 2020.

NAPOLEÃO, D. C.; BRANDÃO, Y. B.; BENACHOUR, M.; SILVA, V. L. Estudo do processo Foto-Fenton para tratamento de fármacos: otimização e modelagem cinética. Sci Plena, v. 9, n. 9, p. 1-9, 2013.

NASCIMENTO, G. E.; CAVALCANTI, V. O. M.; SANTANA, R. M. R.; RODRÍGUEZ-DÍAS, J. M.; VENDAS, D. C. S.; NAPOLEÃO, D. C.; DUARTE, M. M. M. B. Degradation of a Sunset Yellow and Tartrazine Dye Mixture: Optimization Using Statistical Design and Empirical Mathematical Modeling. Water Air Soil Pollut, v. 231, n. 254, p. 2-17, 2020.

NASCIMENTO, G. E.; NAPOLEÃO, D. C.; SANTANA, R. M. R.; CHARAMBA, L. V. C.; OlIVEIRA, J. G. C.; MOURA, M. C.; COELHO, L. C. B. B.; DUARTE, M. M. M. B. Degradation of textile dyes Remazol Yellow Gold and reactive Turquoise: optimization, toxicity and modeling by artificial neural networks. Water Sci Technol, v. 2017, n. 3, p. 812-823, 2018.

National Center for Biotechnology Information. PubChem Compound Summary for CID 11979793, C.I. Acid Black 172. https://pubchem.ncbi.nlm.nih.gov/compound/C.I.-Acid-Black-172. Accessed Mar. $21,2021$. 
NIDHEESH, P. V.; GANDHIMATHI, R.; RAMESH, S. T. Degradation of dyes from aqueous solution by Fenton processes: a review. Environ. Sci. Pollut., v. 20, p. 2099-2132, 2013.

OANCEA, P.; MELTZER, V. Kinetics of tartrazine photodegradation by $\mathrm{UV} / \mathrm{H}_{2} \mathrm{O}_{2}$ in aqueous solution. Chem Pap, v. 68, n. 1, p. 105-111, 2014.

OlIVEIRA, R. A. G.; ZANONI, T. B.; BESSEGATO, G. G.; OLIVEIRA, D. P.; UMBUZEIRO, G. A.; ZANONI, M. V. B. The chemistry and toxicity of hair dyes. Quim Nova, v. 37, n. 6, p. 1037-1046, 2014.

PAŹDZIOR, K.; BILIŃSKA, L.; LEDAKOWICZ, S. A review of the existing and emerging technologies in the combination of AOPs and biological processes in industrial textile wastewater treatment. Chem. Eng. J.., v. 376, p. 120597, 2019.

PUNZI, M.; ANBALAGAN, A.; BÖRNER, R. A.; SVENSSON, B-M.; JONSTRUP, M.; MATTIASSON, B. Degradation of a Textile Azo Dye Using Biological Treatment Followed by Photo-Fenton Oxidation: Evaluation of Toxicity and Microbial Community Structure. Chem. Eng. Trans., v. 270, p. 290-299, 2015.

PUNZI, P.; ANBALAGAN, A.; BORNER, R.; SVENSSON, M.; JONSTRUP, M.; MATTIASSON, B. Degradation of a textile azo dye using biological treatment followed by photo-Fenton oxidation: evaluation of toxicity and microbial community structure. Chem. Eng. J., v. 270, p. 290-299, 2015.

RAWAT, D.; SHYMSHARMA, R.; KARMAKAR, S.; SINGHARORA, L.; MISHRA, V. Ecotoxic potential of a presumably non-toxic azo dye. Ecotox Environ Safe, v. 148, p. 528-537, 2018.

ROSA, J. M.; TAMBOURGI, E. B.; VANALLE, R. M.; GAMARRA, F. M. C.; SANTANA, J. C. C.; ARAÚJO, M. C. Application of continuous $\mathrm{H} 2 \mathrm{O} 2 / \mathrm{UV}$ advanced oxidative process as an option to reduce the consumption of inputs, costs and environmental impacts of textile effluents. J. Clean. Prod., v. 246, p. 119012, 2020.

SAHOO, M. K.; MARBANIANG, M.; SHARAN, R. N. UV light-assisted mineralisation and biodetoxification of Ponceau S with hydroxyl and sulfate radicals. Chem Pap, v. 70, n. 8, p. 1066-1077, 2016.

SANTANA, R. M. R.; NASCIMENTO, G. E.; NAPOLEÃO, D. C.; DUARTE, M. M. B. Degradation and kinetic study of Reactive blue BF-5G and Remazol red RB $133 \%$ dyes using Fenton and photo-Fenton process. REGET, v. 21, n. 2, p. 104-118, 2017.

SARKAR, S.; BHATTACHARJEE, C.; CURCIO, S. Studies on adsorption, reaction mechanisms and kinetics for photocatalytic degradation of CHD, a pharmaceutical waste. Ecotox Environ Safe., v. 121, p. 154-163, 2015.

SLAMANI, S.; ABDELMALEK, F.; GHEZZAR, M. R.; ADDOU, A. Initiation of Fenton process by plasma gliding arc discharge for the degradation of paracetamol in water. J. Photochem. Photobiol. A, v. 359, p. 1-10, 2018. 
SOUZA, E. F.; PORTO, M. B.; POMPERMAYER, N. B.; BERGAMO, M. H. S. Comparação dos processos de síntese e do desempenho de fotocatalisadores para a degradação do corante rodamina $B$. Eng Sanit Ambient, v. 23, n. 4, p. 791-799, 2018.

SPARLING, D. W. Ecotoxicology Essentials - Environmental Contaminants and Their Biological Effects on Animals and Plants. London, Elsevier, 2016.

SYAM BABU, D.; SRIVASTAVA, V.; NIDHEESH， P. V.; KUMAR, M. S. Detoxification of water and wastewater by advanced oxidation processes. Sci. Total Environ., v. 696, p. 133961, 2019.

TORRADES, F.; GARCÍA-MONTAÑO, J. Using central composite experimental design to optimize the degradation of real dye wastewater by Fenton and photo-Fenton reactions. Dyes Pigm, v. 100, p. 184-189, 2014.

YOUNG, B. J.; RIERA, N. I.; BEILY, M. E.; BRES, P. A.; CRESPO, D. C.; RONCO, A. E. Toxicity of the effluent from an anaerobic bio reactor treating cereal residues on Lactuta sativa. Ecotoxicol Environ Safe, $v$. 76, p. 182-186, 2012.

ZAIDAN, L. E. M. C.; SALES, R. V. L.; SALGADO, J. B. A.; SILVA, A. M. R. B.; NAPOLEÃO, D. C.; RODRÍGUEZ-DÍAZ, J. M.; MARQUES, O. M.; BENACHOUR, M.; SILVA, V. L. Photodegradation applied to the treatment of phenol and derived substances catalyzed by TiO2/BiPO4 and biological toxicity analysis. Environ. Sci. Pollut. Res., v. 24, p. 6002-6012, 2017.

ZANONI, M. V. B.; YAMANAKA, H. Corantes: caracterização química, toxicológica, métodos de detecção e tratamento. São Paulo, Cultura Acadêmica, 2016.

ZHANG, G.; ZHANG, S. Quantitative structure-activity relationship in the photodegradation of azo dyes. J. Environ. Sci. Int., v. 90, p. 41-50, 2020.

ZHOU, Y.; LU, J.; ZHOU, Y.; LIU, Y. Recent advances for dyes removal using novel adsorbents: A review. Environ. Pollut., v. 252(part A), p. 352-365, 2019.

ZHU, Y.; ZHU, R.; XI, T.; ZHU, J.; ZHU, G.; HE, H. Strategies for enhancing the heterogeneous Fenton catalytic reactivity: A Review. Appl. Catal. B, v. 255, p. 117739, 2019.

\section{HOW TO QUOTE THIS ARTICLE}

OLIVEIRA, M. A. S. et. al Employment of advanced oxidation processes in the degradation of a textile dye mixture: evaluation of reaction parameters, kinetic study, toxicity and modeling by artificial neural networks. Santa Maria, v.25, e12, 2021. Available from: https://doi.org/10.5902/2236117063909. Accessed: Month Abbreviated. Day, year. 